Agnieszka Walega

(Toruń)

\title{
Regionalizm w historii wychowania w ujęciu Antoniego Karbowiaka (aktualność postulatów i dokonań badawczych)
}

\section{Uwagi wstępne}

Współcześnie widoczne jest olbrzymie zainteresowanie historią regionalną, od dziejów poszczególnych regionów i miejscowości po badania dotyczące losów zasłużonych dla danego terenu postaci czy dorobku oświatowo-wychowawczego działających tam szkół oraz instytucji oświatowo-wychowawczych ${ }^{1}$. Ma to $\mathrm{z}$ pewnością związek $\mathrm{z}$ rozwojem koncepcji tzw. małych ojczyzn oraz z dążeniem do zachowania odrębności narodowych i regionalnych $w$ dobie postępującej integracji europejskiej. Nie jest to jednak zjawisko nowe. Badania regionalne $\mathrm{w}$ zakresie historii wychowania $\mathrm{i}$ oświaty $\mathrm{w}$ Polsce mają dhugą $\mathrm{i}$ bogatą tradycję, w którą wkomponowują się także poglądy oraz dorobek pisarski pierwszego w kraju docenta w zakresie historii wychowania - Antoniego Karbowiaka ${ }^{2}$. Warto przybli-

\footnotetext{
${ }^{1}$ L. Mokrzecki, J. Żerko, Regionalizm $w$ badaniach $i$ nauczaniu historii wychowania, „Rozprawy z Dziejów Oświaty" T. XXXII, 1989, s. 198.

${ }^{2}$ Antoni Karbowiak (1856-1919), profesor nadzwyczajny Uniwersytetu Jagiellońskiego, wykładowca historii wychowania, w 1905 r. pierwszy w Polsce uzyskał veniam legendi w zakresie dziejów wychowania i szkół. Autor wielu rozpraw historyczno-oswiatowych, w tym 3-tomowej syntezy pt. Dzieje wychowania i szkól w Polsce w wiekach średnich, t. I: 966-1363, Petersburg 1898, ss. 339; t. II: 1364-1432, Petersburg 1903, ss. 490; t. III: 1432-1510, Lwów 1923, ss. 564, wydawca licznych źródeł do dziejów oświaty. W rękopisie pozostawil 14 tomów Polskiej bibliografii pedagogicznej od najdawniejszych czasów do końca 1916 roku (przechowywane w zbiorach Działu Rękopisów Biblioteki Naukowej PAU i PAN w Krakowie, sygn. 2250). Drukiem ukazał się jedynie fragment tej pracy pt. Bibliografia pedagogiczna (1901-1910), Lwów-Warszawa 1920.

Informacje o życiu i twórczości historyczno-oświatowej A. Karbowiaka przynoszą następujące wydawnictwa: H. Barycz, Zapomniany historyk wychowania $i$ oświaty polskiej. W czterdziestolecie zgonu Antoniego Karbowiaka garść uwag i materiałów, „Przegląd Historyczno-Oświatowy” 1960, nr 1, s. 13-32; idem, Karbowiak Antoni (1856-1919), w: Polski słownik biograficzny, t. 12, z. 52, Wrocław-Warszawa-Kraków 1966, s. 20-23; idem, Antoni Karbowiak - czlowiek i dzieto, w pięćdziesięciolecie zgonu, ,Kwartalnik Historii Nauki i Techniki"1969, nr 2, s. 259-286; A.K. Banach, Antoni Karbowiak (1856-1919), w: Ztota Księga Wydziału Historycznego, pod red. J. Dybca, Kraków 2000, s. 98-105; A. Wałęga, Poczq̨tki akademickiej historii wychowania w Polsce. Antoni Karbowiak (1856-1919), Toruń 2007; A. Szczerba, A. Wałęga, Antoni Karbowiak, w: Stownik biograficzny polskiej historii wychowania, praca zbiorowa pod red. A. Meissnera i W. Szulakiewicz, Toruń 2008, s. 355-367.
} 
żyć jego wkład w tę dziedzinę badań i usytuować go na tle współczesnych tendencji tego kierunku badań historyczno-oświatowych.

Zdaniem Jerzego Topolskiego o badaniach regionalnych możemy mówić wówczas, gdy badacz analizuje pewne części większego terytorium czy państwa. Przy czym podkreśla on, że „podstawy wydzielenia regionu mogą być różne, zależnie od potrzeb badania" oraz przypomina historykom o konieczności łącznego ujmowania w pracach historii regionalnej, narodowej oraz powszechnej ${ }^{3}$. Badania tego typu niosą ze sobą jednocześnie olbrzymie możliwości, ale i pewne niebezpieczeństwa. W trakcie przeprowadzonej w 1980 r., w gronie historyków, dyskusji dotyczącej metodologii i znaczenia regionalnych badań oświatowych, opublikowanej następnie na łamach „Przeglądu Historyczno-Oświatowego" ${ }^{\text {, }}$, omówione zostały główne problemy dotyczące organizacji tego typu prac. Uczestnicy dyskusji zwrócili uwagę na kilka kwestii podstawowych dotyczących metodologii badań, przygotowania badaczy i dostępności źródeł oraz ogólnego znaczenia wyników badań regionalnych. Podkreślili potrzebę ujednolicenia celów badań regionalnych i ogólnych, unikania przyczynkarstwa, konieczność kształtowania świadomości metodologicznej badaczy regionalistów oraz poszerzania ich szeregów m.in. przez popularyzację i włączanie do badań młodzieży i nauczycieli. Wyraźnie zasygnalizowali przydatność badań i prac cząstkowych dla późniejszych opracowan o charakterze syntez, bogactwo źródeł do dziejów lokalnego szkolnictwa oraz znaczenie regionalnych badań zespołowych.

Dyskusja ta wskazuje na współczesne problemy i tendencje w rozwoju regionalnych badań historyczno-oświatowych i stanowi doskonałe to porównawcze dla dokonań krakowskiego historyka wychowania żyjącego na przełomie XIX i XX w.

\section{Postulaty Antoniego Karbowiaka dotyczące regionalnych badań historyczno-oświatowych}

Antoni Karbowiak mówiąc o badaniach regionalnych, które zwykle określał mianem „lokalnych", zwracał uwagę na ich trzy główne zadania. Miały one przede wszystkim inspirować społeczeństwo do zainteresowania historią, popularyzować wiedzę historyczną oraz skłaniać do działań na rzecz właściwej organizacji tego typu badań (przez np. właściwe zabezpieczenie materiałów źródłowych czy powołanie lokalnych kół badawczych) ${ }^{5}$. Wielokrotnie przypominał on o konieczności popularyzowania wyników historycznych badań naukowych wśród szerokich kręgów społeczeństwa. Za właściwy środek do realizacji tego celu uznawał odpowiednie publikacje, do których zaliczał także, przeznaczone dla najmłodszych dzieci, czytanki szkolne o tematyce historycznej ${ }^{6}$. To z popularyzacją właśnie

\footnotetext{
${ }^{3}$ J. Topolski, Metodologia historii, Warszawa 1968, s. 408-409.

${ }^{4}$ Dyskusja nad rolq badań regionalnych dla historii oświaty (w dniu 23 III 1980 roku), ,Przegląd Historyczno-Oświatowy" 1981, nr 2, s. 182-212.

${ }^{5}$ Według współczesnych historyków wychowania badania regionalne spełniają wiele funkcji, m.in. naukową, kulturalną, kształcącą, wychowawczą oraz właśnie inspiratorską, popularyzatorską oraz organizatorską. Zob. L. Mokrzecki, J. Żerko, op.cit., s. 2-1.

${ }^{6}$ A. Karbowiak, Uwagi o wartości, naszem znawstwie i badaniu ojczystych dziejów nauczania $i$ wychowania, „Nauka Polska" 1919, R. 2, s. 473-475.
} 
wiązał nadzieje na poszerzenie grona badaczy problematyki historyczno-oświatowej, liczył, że zainspiruje ona młodsze pokolenie do tego typu aktywności ${ }^{7}$.

O tym, że owa inspiracja i rozbudzenie świadomości historycznej społeczeństwa było wówczas dla krakowskiego badacza niezwykle istotne, świadczy jego apel zamieszczony we „Wstępie" do pracy pt. Rusyfikacja $i$ bojkot szkół w Królestwie Polskim ${ }^{8}$. Wyraził wówczas nadzieję, że jego publikacja wpłynie na zmianę dotychczasowego, dość lekceważącego, stosunku Polaków do gromadzenia dokumentów dotyczących tych kwestii i wywoła szerszą dyskusję społeczną. Jednocześnie zaznaczył, że literatura i źródła na ten temat, które udało mu się zdobyć, były co prawda liczne i różnorodne, ale także niejednokrotnie pełne sprzeczności ${ }^{9}$. Pośrednio wskazał więc także na konieczność podjęcia badań nad tym zjawiskiem przez osoby kompetentne, które dokonają odpowiedniej analizy i krytyki materiałów źródłowych.

Karbowiak zwracał zatem szczególną uwagę na odpowiednie merytoryczne przygotowanie profesjonalnych historyków regionalistów, ale jednocześnie zachęcał do działań także szersze kręgi społeczeństwa. Zależało mu bowiem na tym, aby także amatorzy mogli efektywnie włączyć się do tego typu badań. Dążył do tego, by zebrane przez nich materiały $\mathrm{i}$ informacje były przydatne dla innych, kompetentnych w tej dziedzinie badaczy. Świadczy o tym m.in. opracowany przez niego, w celu gromadzenia podstawowych informacji o historii oświaty i wychowania w poszczególnych miejscowościach kraju, specjalny 13-punktowy kwestionariusz ${ }^{10}$. Godny podkreślenia jest fakt, że punkty 12 i 13 powyższego kwestionariusza dotyczyły szerszych kwestii i wykraczały poza zagadnienia wąsko pojmowanej historii regionalnej. Karbowiak pytał w nich o materiały dotyczące „powszechnych dziejów pedagogii i szkół w Polsce” oraz wiadomości „do dziejów nauki prywatnej po domach lub o podróżach zagranicznych dla edukacji"'11.

Wszystkie zebrane w ten sposób informacje miały pomóc przy opracowaniu syntez z zakresu dziejów wychowania i szkolnictwa w Polsce, nad którymi mieli już pracować profesjonalni badacze ${ }^{12}$ oraz wzbogacić zbiory Polskiego Muzeum Szkolnego ${ }^{13}$. Uważał,

\footnotetext{
${ }^{7}$ A. Karbowiak, Stan badań na polu wychowania, sztuk i nauk w Polsce, w: Pamiętnik III Zjazdu Historyków Polskich w Krakowie. Protokoty obrad, Kraków 1901, s. 9.

${ }^{8}$ A. Karbowiak, Rusyfikacja i bojkot szkót w Królestwie Polskim, „Muzeum” 1907.

9 Ibidem, s. 263.

${ }^{10}$ Wszystkie pytania tego kwestionariusza odnaleźć można w pracach: W. Szulakiewicz, Historia oświaty i wychowania w Polsce 1918-1939. Studium historiograficzne, Torun 2000, s. 250-251; A. Wałęga, Poczq̨tki akademickiej, s. 61.

${ }^{11}$ A. Karbowiak, W sprawie badań dziejów wychowania $i$ szkót w Polsce. Odezwa, „Muzeum” 1901, s. $315-316$.

${ }^{12}$ Ibidem, s. 315 .

${ }^{13}$ Temat ten podejmował Karbowiak wielokrotnie: Listy $w$ sprawie wystawy historycznej szkolnictwa narodowego, „Muzeum” 1893; Listy w sprawie wystawy rzeczy szkolnych polskich, „Muzeum” 1894; Stan badań, s. 9-10.

Literatura na temat Polskiego Muzeum Szkolnego: A. Knot, Polskie Muzeum Szkolne we Lwowie, „Minerwa Polska" t. 1, nr 2/1927; J. Szews, $O$ utworzenie Muzeum Historii Oświaty, „Gdańskie Zeszyty Humanistyczne” 1964, R. 7, nr 12; A. Głowacka, Z dziejów Polskiego Muzeum Szkolnego, „Zeszyty Naukowe Uniwersytetu Adama Mickiewicza w Poznaniu. Biblioteka" 1966, nr 61.
} 
że właśnie na podstawie prac z zakresu historii regionalnej mogą powstawać wartościowe publikacje o charakterze ogólnym.

Karbowiak niezwykle cenił opracowania ogólne i syntezy. W 1909 r., apelując do rodaków o podjęcie badań nad zagadnieniem polskiej emigracji, wyraźnie zaznaczył, że sprawa ta wymaga szerokich poszukiwań, działań grupowych i odejścia od „ciasnych granic lokalnych" i „odosobnionego lokalnego punktu widzenia". Dotychczasowe prace cząstkowe na ten temat uznał za niewystarczające i wezwał do podjęcia zbiorowego wysiłku nad zmianą niekorzystnej sytuacji w tym zakresie ${ }^{14}$. Uważał bowiem, że tylko całościowe, wnikliwe opracowanie problematyki edukacji polskich emigrantów na świecie uświadomi całemu społeczeństwu ogromną skalę zaniedbań i zagrożeń oraz skłoni do refleksji ${ }^{15}$.

Dowodem na to, że Karbowiak przykładał wielką wagę do badań regionalnych w dziedzinie oświaty są także jego częste porównania nikłego polskiego dorobku w tej dziedzinie $\mathrm{z}$ dokonaniami narodu niemieckiego. Uczulał rodaków na te kwestie i jej istotne znaczenie, nawoływał, by tak, jak u zachodnich sąsiadów „liczne prowincjonalne Towarzystwa historyczne opiekowały się m.in. i lokalną historią szkół i pedagogii"16.

Wytyczał także konkretne kierunki badań regionalnych w zakresie historii wychowania i szkolnictwa. W 1900 r. na III Zjeździe Historyków Polskich w Krakowie zaznaczył konieczność opracowania dziejów szkolnictwa polskiego wszystkich szczebli - od parafialnego rozpoczynając na szkolnictwie wyższym kończąc. Zaznaczył, że w roku 1772 w Polsce istniało około 130 szkół gimnazjalnych, a do początku wieku XX zaledwie dla $25 \mathrm{z}$ nich przygotowano opracowania monograficzne, $\mathrm{i}$ to $\mathrm{w}$ większości niepełne, obejmujące głównie najnowsze dzieje tych placówek ${ }^{17}$. W 1901 r., nawiązując do swego wcześniejszego pomysłu, proponował opracowanie monografii dotyczącej dziejów wszystkich szkół krakowskich, przypominając, że ich tradycje sięgają wieku $\mathrm{XV}^{18}$.

Zdawał sobie jednak sprawę z tego, że jest to niezwykle żmudne zadanie badawcze. Dlatego też nawoływał do podejmowania prac zbiorowych w zakresie historii regionalnej, które ze względu na bogate zasoby lokalnych archiwów parafialnych, publicznych, konsystorskich i prywatnych wymagają licznego grona badaczy zaangażowanych w opracowywanie jednego zagadnienia ${ }^{19}$. Sam doskonale przekonał się o tym, gromadząc materiały do swojej pracy pt. Szkoly diecezji chetmińskiej $w$ wiekach średnich, która ostatecznie, jak sam pisał, miała stanowić jedynie ,zestawienie materiałów znanych obecnie co do tego tematu, by ułatwić dalsze poszukiwanie w tym zakresie. Może zachęcić zwłaszcza duchowieństwo parafialne do badań archiwalnych"20. Propagował zatem ,na-

\footnotetext{
${ }^{14}$ A. Karbowiak, Towarzystwo Polskiego Muzeum Edukacyjnego, „Muzeum” 1909, s. 136-137.

${ }^{15}$ Sam podjął taką próbę w swoich dwóch większych pracach poświęconych emigrantom polskim: Dzieje edukacyjne Polaków na obczyźnie, Lwów 1910 i Mtodzież polska akademicka za granica 1795-1910, Kraków 1910 oraz w zamieszczonym na łamach „Szkoły” (1909) obszernym artykule pt. Polska literatura pedagogiczna na obczyźnie1830-1909. Szerzej na ten temat: A. Wałęga, Poczqtki akademickiej, s. 106-122.

${ }^{16}$ A. Karbowiak, $W$ sprawie badań, s. 310.

${ }^{17}$ A. Karbowiak, Stan badań, s. 5.

${ }^{18}$ A. Karbowiak, W sprawie badań, s. 314.

${ }^{19}$ A. Karbowiak, Szkoty diecezji chelmińskiej w wiekach średnich, Toruń 1899, s. 5.

${ }^{20}$ Ibidem, s. 8.
} 
ukowe poszukiwania lokalne"21, które miały doprowadzić do zgromadzenia, krytycznego opracowania oraz umiejętnego wykorzystania rozproszonych materiałów. Ich efektem miały być liczne monografie, które ułatwią pracę kolejnym, dążącym już do syntezy historiografom ${ }^{22}$.

\section{Regionalizm w twórczości pisarskiej Antoniego Karbowiaka}

Działalność pisarska Karbowiaka przypadła na okres zaborów, co niejako w sposób naturalny zmusiło go do prowadzenia regionalnych badań historycznych $\mathrm{z}$ jednej strony warunkowanych dostępnością materiałów źródłowych i możliwością poruszania określonych tematów, $\mathbf{z}$ drugiej natomiast odrębnością systemów edukacyjnych i wychowawczych poszczególnych ziem polskich. W $1981 \mathrm{r}$. w trakcie dyskusji nad rolą badań regionalnych zwrócił na to uwagę Ryszard Wroczyński: „W polskiej historiografii oświatowej studia regionalne zajmują poważne miejsce. Wynika to ze zróżnicowania regionalnego naszego kraju, co może nie jest cechą specyficzną tylko dla nas [...]. Natomiast regionalna historiografia oświatowa pełni u nas szczególną rolę ze względu na polityczne losy kraju. Podziały rozbiorowe sprawiły wielkie zróżnicowanie oświatowe poszczególnych obszarów ziem polskich",23.

Karbowiak pochodził z Wielkopolski, ale już w okresie studiów na Wydziale Filozoficznym Uniwersytetu Jagiellońskiego związał się ściśle z terenem Galicji, w której żył i pracował jako nauczyciel szkół średnich i wykładowca akademicki do końca swojego życia. Niejako naturalnym następstwem tego jest znaczący udział, jaki w bibliografii jego prac mają publikacje poświęcone krakowskiej uczelni ${ }^{24}$ oraz galicyjskiej historii oświaty i wychowania ${ }^{25}$. Nie zapomniał jednak o swoich korzeniach i mimo utrudnionego dostępu do źródeł archiwalnych opracowywał również prace dotyczące

\footnotetext{
${ }^{21}$ Ibidem, s. 9.

${ }^{22}$ A. Karbowiak, Stan badań, s. 11.

${ }^{23}$ R. Wroczyński, Gtos w dyskusji, w: Dyskusja nad rola badań regionalnych, s. 211.

${ }^{24}$ Strój żaków Uniwersytetu Jagiellońskiego w XV-XVI wieku, „Przegląd Powszechny”, T. XII, Kraków 1886; Ilustracje polskie z życia uniwersyteckiego XVI-XVIII wieku, Kraków 1887; Mieszkania żaków krakowskich w XIV-XVI wieku, Lwów 1887, odb. z „Muzeum"; O rektorach Uniwersytetu Kazimierzowskiego i Jagiellońskiego w Krakowie, Kraków 1887, odb. $\mathrm{z}$ „Kroniki Uniwersytetu Jagiellońskiego”; Ubiory profesorów $i$ uczniów w Uniwersytecie Jagiellońskim w zwiqzku z wspótczesnymi zwyczajami (1364-1889), Kraków 1890 odb. z „Przeglądu Powszechnego”; Ustawy bursy krakowskiej Jeruzalem (1453-1841), Kraków 1888 oraz T. VI „Archiwum do Dziejów Literatury i Oświaty w Polsce”; Obiady profesorów Uníwersytetu Jagiellońskiego w XVI i XVII wieku, „Biblioteka Krakowska” nr 13, Kraków 1900; Kobieta w Uniwersytecie Jagiellońskim w XV wieku, ,Muzeum” 1904; Studia statystyczne z dziejów Uniwersytetu Jagiellońskiego od roku 1433/1434-1509/1510, Kraków 1905 oraz t. XII „Archiwum do Dziejów Literatury i Oświaty w Polsce".

${ }^{25}$ Przegląd dziejów c.k. gimnazjum wadowickiego, Wadowice 1892; Ruch naukowo-literacki nauczycieli szkót wyższych galicyjskich w ostatnich 25 latach, „Przegląd Powszechny” 1892; Szkola katedralna krakowska w wiekach średnich, Kraków 1899, odb. z „Muzeum”; Rozproszenie mtodzieży szkolnej krakowskiej w 1549 roku, Kraków 1900.
} 
szkolnictwa na terenach zaboru pruskiego ${ }^{26}$. Trudności w pracy naukowej nigdy go nie zrażały, a doskonały dowód na to stanowią publikacje poświęcone niezwykle trudnej sytuacji polskiego szkolnictwa pod zaborem rosyjskim ${ }^{27}$. Podejmując problematykę szkolnictwa polskiego pod zaborami nie unikał także ujęć porównawczych, o czym świadczy m.in. jego szkic pt. Obecne systemy wychowawcze na ziemi polskiej $w$ trzech zaborach ${ }^{28}$.

Warto też zaznaczyć, że w swoich pracach dotyczących okresu średniowiecza i renesansu często odwoływał się do metod badawczych charakterystycznych dla badań regionalnych, tj. do metody porównawczej ${ }^{29}$ oraz omawiał np. szkoły według ich przynależności do poszczególnych diecezji ${ }^{30}$.

O jego stosunku do badań regionalnych wymownie świadczą słowa, które zawarł w swojej pracy pt. Bydgoszcz a Pakość. Karta z dziejów wychowania i szkól Księstwa Warszawskiego. We „Wstępie” podkreślił, że chociaż ogranicza się w publikacji jedynie do „wiązanki" charakterystycznych szczegółów z dziejów wychowania i szkół Księstwa Warszawskiego i opisuje szczegółowo tylko dwie placówki, to „rzucają one sporo światła na stan ogólny ówczesnych spraw edukacyjnych"31. Krakowski historyk wychowania wielokrotnie zaznaczał, że jego nawet najdrobniejsze prace mają stanowić wkład w wyjaśnianie zjawisk oświatowych w szerszych kontekstach. Podsumowując swoją drobną pracę pt. Obiady profesorów Uniwersytetu Jagiellońskiego w XVI $i$ XVII wieku stwierdzał, że przybliża ona obraz zwyczajów i ukazuje poziom rozwoju cywilizacyjnego średniozamożnych wykształconych Polaków na przestrzeni lat 1550-1650.

$\mathrm{Na}$ ten problem zwrócił współcześnie uwagę Jerzy Topolski, który podkreślił, że w badaniach o charakterze cząstkowym i regionalnym ,chodzi o integralne traktowanie podjętego badania, czyli o umiejętność osadzenia go w szerszym kontekście i zdawanie sobie sprawy z różnego rodzaju powiązań z ogólnym procesem historycznym". Jako przykład podał badania nad guzikami mieszczan poznańskich, które można potraktować dwojako: jako prosty opis owych guzików bądź jako element ukazujący mentalność ich szlacheckich właścicieli ${ }^{32}$.

\footnotetext{
${ }^{26}$ Bydgoszcz a Pakość. Karta z dziejów wychowania i szkół Księstwa Warszawskiego, „Muzeum" 1897 i osobne odb.; Szkoły diecezji chetmińskiej $w$ wiekach średnich, Toruń 1899; Materiaty do dziejów wychowania i szkót w ziemi chetmińskiej 1808-1814, Toruń 1900; Szkoła pruska w ziemiach polskich, „Muzeum" 1903 oraz osobne odb. Lwów 1904; U źródel odrodzenia narodowego na Śląsku Górnym, „Świat Słowiański" 1908 i osobne odb.; Problem wychowania narodowego $w$ dzielnicy pruskiej, „Muzeum" 1913.

${ }^{27}$ Rusyfikacja i bojkot szkót w Królestwie Polskim, „Muzeum” 1907; Ruch pedagogiczny w Królestwie Polskim w dobie bojkotu, „Muzeum” 1908.

${ }^{28}$ Obecne systemy wychowawcze na ziemi polskiej $w$ trzech zaborach, „Muzeum" 1905.

${ }^{29} \mathrm{O}$ metodzie porównawczej zob. m.in. C. Majorek, Metoda porównawcza w badaniach historyczno-oświatowych, „Przegląd Humanistyczny” 1979, nr 7. Szerzej na temat tego aspektu badań Karbowiaka zob. A. Wałęga, Poczq̨iki akademickiej, s. 67-71.

${ }^{30}$ Por. m.in. prace Karbowiaka, Szkoty parafialne w Polsce w XIII i XIV wieku, Kraków 1897; Szkoły diecezji chetmińskiej; Dzieje wychowania $i$ szkół $w$ Polsce, t. I-III, Petersburg-Lwów 1898-1923.

${ }^{31}$ A. Karbowiak, Bydgoszcz a Pakość, s. 3.

${ }^{32} \mathrm{~J}$. Topolski, $O$ przedmiocie $i$ metodologii badań regionalnych $w$ zakresie historii oświaty, "Przegląd Historyczno-Oświatowy" 1981 , nr 2, s. 174.
} 
Karbowiak zatem, dostrzegając w opisie obiadów krakowskiej profesury odzwierciedlenie historii rozwoju kulturowego i obyczajowego tej specyficznej grupy społecznej, zastosował w swoich badaniach perspektywę wyjaśniającą i syntetyczną. Zdecydowanie świadczą o tym jego słowa: „szkic nasz dostarczył sporo dowodów, że gruntowne badanie na tem polu w tym kierunku mogą nam otworzyć szerokie widnokręgi na dzieje zwyczajów i kultury polskich dawnych czasów"33. Z pewnością nie można mu w tym przypadku zarzucić przypisywanego tradycyjnej, pozytywistycznej historiografii, izolowanego sposobu przedstawiania spraw i niedostrzegania ich szerszego znaczenia.

Krakowski historyk doskonale rozumiał potrzebę prowadzenia wnikliwych, ale jednocześnie integralnych badań, które pozwolą na uogólnienia i syntezy. Dlatego nawet tak drobna kwestia, jak posiłki profesorów najstarszego polskiego uniwersytetu miała dla niego ogromne znaczenie, jak przewidywał bowiem: „spostrzeżenia poczynione w tej właśnie warstwie społeczeństwa rzucają sporo światła i na analogiczne stosunki innych klas społecznych, zbliżonych życiem do ówczesnej jakbyśmy dziś powiedzieli inteligencji”34. Podobnie, gdy pisał o strojach studentów i profesorów uczelni krakowskiej ${ }^{35}$ rozpatrywał te kwestie w kontekście silnych związków łączących średniowieczne szkolnictwo z Kościołem oraz nawiązywał do pytań o zasadność wprowadzania odrębnego stroju szkolnego. Przedstawiał zatem te kwestie jednocześnie na szerszym tle historycznym i pedagogicznym.

Sam w praktyce realizował też swoje postulaty dotyczące badań regionalnych. Jest bowiem Karbowiak autorem licznych prac o charakterze syntez, wśród nich warto wymienić największe jego dzieło (i to nie tylko pod względem objętościowym), Dzieje wychowania i szkót $w$ Polsce $w$ wiekach średnich (t. I-III) obejmujące okres od 966 do $1510 \mathrm{r}^{36}$ Do czasów współczesnych wielu historyków i historiografów podkreśla fundamentalne znaczenie tej publikacji dla dalszych badań nad dziejami średniowiecznej polskiej oświaty ${ }^{37}$.

Należy zaznaczyć, że zarówno w tej, jak i w innych tego typu swoich książkach, pierwszy polski docent historii wychowania zamieszczał wyniki wcześniejszych cząstkowych badań. Włączał zatem wyniki badań regionalnych (własnych i cudzych) do ujęć syntetycznych. Ponieważ na przełomie XIX i XX w. historia wychowania dopiero kształtowała się jako dyscyplina naukowa, musiał on jednocześnie gromadzić materiały, pisać prace przyczynkarskie, a dopiero na ich podstawie ogólniejsze opracowania ${ }^{38}$. Przy

${ }^{33}$ A. Karbowiak, Obiady profesorów, s. 57.

${ }^{34}$ Ibidem, s. 51-52.

${ }^{35}$ A. Karbowiak, Strój żaków; Ubiory profesorów i uczniów.

${ }^{36}$ A. Karbowiak, Dzieje wychowania $i$ szkól w Polsce, t. I, II i III.

${ }^{37}$ M.in. H. Barycz, Antoni Karbowiak-czlowiek $i$ dzieło, s. 273; J. Maternicki, Historiografia polska XX wieku, cz. I, Lata 1918-1939, Wrocław 1982, s. 146. Szerzej na ten temat A. Wałęga, Początki akademickiej, s. 74-83.

${ }^{38} \mathrm{Na}$ ten problem zwrócił uwagę m.in. Andrzej Meissner podkreślając, że wśród galicyjskich publikacji historyczno-oswiatowych tamtego okresu dominowały prace przyczynkarskie i sprawozdawcze, a brakowało ujęć syntetycznych. Jako wyjątek podal, obok prac Karbowiaka, publikacje Kazimierza Morawskiego, Ludwika Janowskiego oraz Stanisława Kota. Zob. A. Meissner, Wktad Galicji w rozwój historii wychowania, „Chowanna” 1998, R. XLI, T. 2, s. 57-58. 
obciążeniu Karbowiaka pracą nauczycielską oraz licznymi trudnościami w dostępie do źródeł (także tymi wynikającymi z ówczesnej sytuacji politycznej kraju), jego dorobek w tym zakresie trzeba uznać za znaczący.

\section{Uwagi końcowe}

Antoniego Karbowiaka bezsprzecznie uznać można za jednego ze współtwórców nie tylko historii wychowania jako dyscypliny naukowej i akademickiej ${ }^{39}$, ale również za historyka propagującego regionalizm w badaniach historyczno-oświatowych. Przez swoje postulaty i wystąpienia propagował on te zagadnienia w kręgach zarówno historyków, jak i pedagogów, a przez swoje publikacje wskazywał drogę kolejnym badaczom.

Dostrzegał już na przełomie wieku XIX i XX potrzebę prowadzenia zakrojonych na szeroką skalę regionalnych badań zespołowych, ukierunkowanych wyraźnym planem, które w efekcie pozwola na stworzenie opracowań o charakterze syntez. Sam podawał nawet konkretne kierunki takich poszukiwań i nie znajdując szerszego poparcia dla swoich koncepcji samodzielnie starał się je realizować. Chciał przez to wykazać, że pomimo licznych ograniczeń można w tym zakresie osiągnąć znaczące efekty. Świadczy o tym nie tylko cykl jego opracowań regionalnych i monograficznych, ale przede wszystkim stanowiące ich zwieńczenie dzieło Dzieje wychowania i szkót w Polsce w wiekach średnich.

Doceniał także znaczenie działań popularyzatorskich oraz konieczność włączania do badań regionalnych szerszych kręgów społeczeństwa - przede wszystkim młodzieży, nauczycieli i duchownych.

Szczególnie ważne i warte podkreślenia wydaje się być to, że mimo zarzucanej mu postawy idiograficznej $i$ hołdowania pozytywistycznemu modelowi nauki historycznej ${ }^{40}$ dostrzegał szersze konteksty badanych przez siebie zjawisk lokalnych. Zatem doskonale realizował wskazówkę metodologiczną Jerzego Topolskiego, który zalecał, by „Jeśli [...] ktoś podejmuje np. badanie dotyczące działalności jakiejś osoby, niezbędne jest, by zdawał sobie sprawę z tego, co zbadanie tej działalności wniesie do poznania całego procesu historycznego (choćby w danej dziedzinie), co przez to ma zostać wykazane, co takie badanie wyjaśni, jaki szerszy problem historyczny naświetli itp." ${ }^{.41}$.

Dlatego też wydaje się słuszny postulat, aby mówiąc o tradycjach polskich regionalnych badań historyczno-oświatowych nie pomijać postaci i dorobku Antoniego Karbowiaka.

\footnotetext{
39 Por. A. Wałęga, Poczq̨tki akademickiej.

${ }^{40}$ Por. J. Maternicki, Polskie środowisko historyczne w latach 1900-1918, „Przegląd Humanistyczny" 1980, nr 4, s. 12-13; W. Marmon, Krakowskie środowisko historyczne w latach 1918-1939, Krakb́w 1995, s. 57.

${ }^{41}$ J. Topolski, O przedmiocie i metodologii badań, s. 174.
} 


\section{Regionalism in the History of Education in the Formulation by Antoni Karbowiak (Topicality of Postulates and Scholarly Achievements)}

The article presents the contribution of the first in Poland assistant professor in the field of the history of education, professor of Jagiellonian University, Antoni Karbowiak (1856-1919) to the development of regional historical and educational studies. Karbowiak devoted much attention to the propagation of these studies in his publications, in which he emphasized their import ant role and significance for further development of the history of education. He stressed the need to conduct collective regional studies on a broader scale, according to a precisely defined plan. $\mathrm{He}$ contended that only in this way valuable material can be compiled, which - elaborated by well-prepared scholars - shall enable the creation of worthwhile syntheses. He himself undertook "local" research, as he called it, and repeatedly brought readers' attention to the question of preserving source material found in their closest surroundings for the history of education. He encouraged the creation of regional research organizations and the stimulation of historical consciousness of Polish society, especially children and youth. In order to win new contributors for regional historical and educational studies, he worked out a special 13-point questionnaire on the basis of which it was possible to gather information about local schools and their history.

In his publications, Antoni Karbowiak emphasised that even the smallest papers dealing with regional issues are supposed to contribute to the explanation of educational phenomena in broader contexts. This concept by Antoni Karbowiak perfectly combines into the convention of modern regional studies. 